\title{
Optimizing value creation and value capture with a digital multi-sided business model
}

\author{
Romain Gandia \\ Assistant Professor in Innovation Management \\ Univ. Savoie Mont Blanc / IREGE - France \\ romain.gandia@univ-smb.fr
}

Guy Parmentier

Assistant Professor in Innovation Management

Univ. Grenoble Alpes / CERAG - France

guy.parmentier@iae-grenoble.fr

Corresponding author: rgandia@inseec.com

\begin{abstract}
:
Faced with the limits of cooperative approaches to business model in optimizing the value creation and value capture, we propose here a new multi-sided business model architecture adapted to digital industries which allows considering new opportunities to create and capture value, for the growth and survival of innovative SMEs.
\end{abstract}

Keywords: value creation, value capture, digital business model, multi-sided platform.

This research is supported par the French National Research Agency in the case of the project ANR-13-SOIN-001.

J.E.L. classification codes : L10 


\section{INTRODUCTION}

The business model (BM) is a source of efficiency for firms and entrepreneurs because it allows managers to reflect on how to optimize value creation, by multiplying its sources, and value capture, by increasing revenue within and outside the firm's boundaries (Chesbrough and Rosenbloom, 2002; Teece, 2010). However, true optimization of these two elements remains a challenge for many firms, especially for innovative small and medium enterprises (SMEs) because of their limited resources. Under these conditions, the BM is often collaborative, that may cause negative effects. Although collaboration fosters value creation (Chesbrough and others, 2006; Stuart, 2000), it may limit value capture in that partners share the revenue from innovation (Chesbrough and others, 2006). In addition, cooperation does not exclude dependence phenomena (Gulati and Stych, 2007), opportunistic behaviors or conflicts of intellectual property, which can limit value creation and value capture (Pisano and Teece, 2007). To counteract these negative effects, SMEs must aim to more intelligently organize the BM components to optimize value creation and value capture. In digital industries, some SMEs seem have found a solution by developing a BM with a multi-sided platform.

Indeed, literature focusing on platforms and multi-sided markets (Evans and Schmalensee, 2007; Rochet and Tirole, 2006) proposes a possible solution that considers the BM as not a single object but a plural object with multiple sides. With the declining costs of acquiring information and intermediation, many multifaceted platforms have emerged on Internet (for example: Ebay, Amazon, Youtube, Airbnb). These platforms adopt a BM based on intermediation and networking user categories that are complementary and interdependent. Using this approach, a SME can develop a multi-sided BM and break it down into multiple sides to optimize value creation and 
value capture (through categories of customers, products and services). Thus, it is possible to cooperate on certain sides of the BM to optimize value creation and keep internal control of key resources on other sides to optimize value capture. We believe that the key to value optimization lies in managing the interactions and interdependence between the different sides of the BM. This paper addresses the following question: how optimize value creation and value capture with a multi-sided BM? To address this issue, we first develop our theoretical framework on BM and multi-sided platforms. Next, we present our methodology and the selected cases of video game BMs. Finally, we present the results and discuss the theoretical and managerial implications.

\section{THEORITICAL BACKGROUND}

The BM is a model (Baden-Fuller and Morgan, 2010) that conceptualizes the way a firm organizes its value creation in a value chain and value network, its value proposition and its value capture through a revenue model (Teece, 2010). Value creation can be defined as the invention or reconfiguration of assets and skills to create a usage value (new product, new service) subjectively viewed as new and relevant for potential users (Lepak and others, 2007, p. 182). Value proposition can be defined as a promise of value to be delivered to a specific target customer segment (DubossonTorbay and others, 2002). Value capture can be defined as the firm’s capacity to capture a material (income) or an immaterial (for example: knowledge, reputation) value received in exchange for a usage value, created for potential users (Dubosson-Torbay and others, p. 182). The BM is a key element for firms and entrepreneurs aiming to optimize value creation and value capture. However, true optimization of these two elements remains a challenge for innovative SMEs, especially because they must 
cooperate to create and distribute their innovative products or services (Wolff and Pett, 2006). This collaborative dimension may cause negative effects that traditional BM architectures fail to completely solve.

\subsection{Limits of traditional BM architecture in a collaborative approach}

For innovative SMEs, collaboration in BM poses several problems. In the case of collaboration with an industrial partner, participation in value creation often leads to that partner's involvement in the value proposition, which ultimately limits the level of value capture for both partners (Chesbrough and Appleyard, 2007). Other factors can decrease value creation performance and value capture because collaboration can cause opportunism, conflicts of intellectual property (Chesbrough and others, 2006; Yunus and others, 2010), power imbalance and dependence (Casciaro and Piskorski, 2005) and uncertainty in the distribution of results (Chesbrough and Appleyard, 2007). In the case of collaboration with users, which often occurs in the digital industry (Wirtz and others, 2010), capturing user-created value can be difficult if the SME does not initially associate users with the owner of the value creation (Jeppesen and Frederiksen, 2006). Similarly, value creation is hampered when end users do not recognize the value proposition or have conflicting interests and motivations (Dahlander and Magnusson, 2008). Collaboration in value capture can lead to intellectual property conflicts relating to value creation (Fichter, 2009) or in the case of inadequacy of the value proposition to the target consumer and market segments selected (Porter, 2001). For SMEs, value optimization in a BM remains a challenge due to negative effects imply by collaboration but also because traditional BM architectures are limited to solve these effects. 
$\mathrm{BM}$ is an interdependent activity system in which the components of value creation, value proposition and value capture are connected (Zott and Amit, 2010). In this way, a collaboration in one component, as the value creation, can have negative repercussion on the other components (for example: loss of value creation control, loss of income, loss of decision-making control). Thus, the value optimization remains complex. Another solution is to develop an architecture based on a BM portfolio (Sabatier and others, 2010) to multiply sources of value creation and income. This architecture offers the possibility of collaborating on one BM to access technologies, key external resources and so on and developing another BM independently to capture more value with the licensing, the valorization of products and services in other markets and so on (Sabatier and others, 2010). However, if SMEs have insufficient internal resources to develop their BM portfolio, cooperation remains essential, and negative effects can be multiplied. In addition, managing a portfolio of BMs requires strong organizational skills, which can be difficult to acquire and implement for innovative SMEs (Sabatier and others, 2010). The last solution is to connect two complementary BMs (owned by two firms) to create a dual BM architecture ${ }^{1}$ (Markides and Charitou, 2004). This architecture allows both firms to generate positive network effects that can optimize value creation and value capture. Even if this architecture does not solve the negative effects of the collaboration (because each BM is owned by different firms), it provides strategic reflections to build a $\mathrm{BM}$ architecture with complementary and connected sides in order to generate positive network effects that will be a lever for

\footnotetext{
${ }^{1}$ Example: the dual BM of Nespresso (Markides and Charitou, 2004) which offers coffee machines in one side and coffee capsules in other side (two sources of value creation and value capture) with one value proposition based on the coffee consumption. Positive network effects appear because (1) the greater the number Nespresso machines sold, the more effective the BM of capsules is, and (2) the greater the diversity of capsules, the more customers want to buy Nespresso machines.
} 
value optimization. This type of architecture leads us to deepen the concept of side using the literature on multi-sided platforms.

\subsection{Contributions of multi-sided approach to BM architecture}

The multi-sided approach is based on the theoretical concept of a multi-sided platform ${ }^{2}$ which provides an effective means of optimizing value creation and value capture. In digital industries, a multi-sided platform is an economic environment based on a service market-place (for example: Ebay) in which products and services are sold to different groups of users (Eisenmann and others, 2006; Roson, 2005). By organizing and facilitating transactions between the user groups, the platform allows to generate network effects. Within a multi-sided platform, the value of a product or service depends on the direct effects of networks on the same side (value of goods varies with the number of users) and cross-side network effects (value of goods increases with the number of users of other sides and vice versa) (Eisenmann and others, 2006; Katz and Shapiro, 1992).

In such a platform, pricing strongly influences the network effects and the overall value capture generated by the platform (Roson, 2005). In digital industries, platform managers commonly subsidize a side (for example: end users) because the user contribution to a product or service provides an overall value greater than its resultant income (Eisenmann and others, 2006). For example, in a website of content generation structured as a multi-sided platform, the end user may create value in the form of content, creation or events, indicating strong cross-side network effects (direct and indirect) (Albuquerque and others, 2012). In this case, the firm captures a monetary

\footnotetext{
2 This concept is close to a multi-sided market concept (Rochet and Tirole, 2006) or a multi-sided network concept (Roson, 2005). They are similar from the point of view of network effects.
} 
value by billing one or more sides of the platform, and users capture tangible or intangible value by acquiring knowledge, reputation and, by using products and services, more affluence. Thus, a multi-sided platform is characterized by a device for creating value, value proposition and value capture that can be different on each side. A side is characterized by a homogeneous user group with specific needs and behaviors, which represents a market segment or an entire market (Evans and Schmalensee, 2007). A multi-sided platform can gather different user groups interacting with one another and cause positive network effects intra-market or inter-market (Parker and Van Alstyne, 2005). Internet platforms promote strong network effects because the transaction costs are low, acquiring users is less expensive than physical platforms and social effects are strong (Shuen, 2008).

To create a multi-sided platform, it is necessary to conceive a value proposition that will interest several user categories and that provides mutual value. The crux of the problem of creating an effective BM lies in the structuration of the offer, the organization of sides and the apportionment of billing between sides. The choice of a suitable BM in terms of structuration and billing of sides is same decision for the success of a multi-sided platform (Rochet and Tirole, 2003). Implementing an activity in a multi-sided market or platform requires the creation of a specific BM, which we call the multi-sided BM. We propose that the multi-sided BM allows organization of activities of value creation and value capture of an offer (products and/or services) to complementary and interdependent user/customer categories through positive network effects in one or multiple markets. The multi-sided BM offers several places and types of value creation that lead to one or several value propositions depending on user needs on a side. Network effects between sides produce more value creation than if the sides 
were independent. Moreover, as the firm controls the structuration and the relationships between sides, it is likely to capture the largest share of monetary value, leaving most of the nonmonetary value for users. To examine this emergent concept and its role in optimizing value creation and value capture, we propose to study two SMEs in the digital video game industry that have successfully implemented a multi-sided BM.

\section{METHODOLOGY}

Our study addresses the multi-sided BM in the video game industry. We chose this sector because of its highly competitive nature and rapid technological evolutions, which have driven innovative SMEs to review their BMs. In the video game industry, cooperation with industrial partners and also with users is common because the dematerialization of distribution networks promotes the power of online game communities (Johns, 2006). We chose a qualitative and exploratory methodology (Yin, 2003) because our research object, the multi-sided BM, is a complex object based on a minimum of knowledge (provided by the literature on multi-sided platforms), which first requires the collection of evidence of its existence. In this sense, the exploratory approach is suitable because it can provide knowledge on unknown or not clearly defined phenomena (Yin, 2003). Knowing that a multi-sided BM can be implemented on one or multiple markets, we have selected two innovative SMEs: (1) Nadeo, which has successfully implemented a multi-sided BM in one market with different user groups, and (2) Ankama, which has successfully implemented a multi-sided BM in multiple markets with specific user groups. Our two case studies have nonhomogeneous variables. Nadeo's multi-sided BM is based on the development of one digital platform of a racing game simulation, Trackmania. Ankama's multi-sided BM is based on the development of a digital heroic fantasy universe, Wakfu, which operates in various 
interconnected media and is commercialized in specific markets. Finally, our exploratory approach has a descriptive purpose in that our two case studies describe the optimization of value creation and value capture in a multi-sided BM. Therefore, the study addresses the question "how" (we do not try to measure the optimization), which requires a description of reality, useful in understanding the operation of a phenomenon.

\subsection{Data collection and treatment}

To collect qualitative data, we used a longitudinal approach during a three-year period (2007-2009). A longitudinal study allows us to collect rich data by integrating a historical and contextual dimension (Miles and Huberman, 1994). We preferred this type of study to shed light on the dynamics of BM structuration over time, including the dynamics of optimizing value creation and value capture. We chose to explore the issue by using multiple sources of data collection (see Table 1): semi-structured interview, internal data (project documentation, meeting reports and community reports) and external data (for example: community official and unofficial websites, newsletter.).

\section{[INSERT Table 1]}

We processed the data using thematic coding by combining data from the literature and from the field. We identified five broad categories: (1) multi-sided structuration, (2) value creation, (3) value proposition, (4) value capture and (5) positive network effects. Using the analyzed data, we developed a grid of the themes, also known as a "dictionary of themes." We codified these themes manually, and we distinguish descriptive, explanatory and interpretive information (according to Miles and Huberman, 1994). This grid allowed us to characterize the architecture of Trackmania and Wakfu, qualify the value of transactions between the sides and identify how the two innovative SMEs optimized the value creation and value capture. 


\subsection{Trackmania's digital multi-sided BM}

Nadeo is a producer of PC and console games that focuses on developing and publishing digital sports games. Its flagship game, Trackmania, is a car racing simulation that can be played in single gamer mode or online with tools to create circuits, cars and movies. The producer developed the game in-house and collaborates with distributors for marketing and distribution. Nadeo offers free restricted version and paid versions of the game.

The Trackmania's multi-sided BM is composed of three sides which represent three complementary categories of gamers (creators, managers and competitors) on a single digital platform and one market. Each category of gamers is a side because their needs, behaviors and activities in the game are similar, and they bring added value to all the other gamers (see Table 2). Even if a user can belong to three categories, there are boundaries between them depending upon their role and actions. On Side 1, creators generate new content (circuits, cars and videos) available directly in the game or external websites. In four years, they have created more than 150,000 circuits, tens of thousands of cars and thousands of videos. This content contributes to the overall value of the game by adding diversity, which makes it more interesting for competitors and managers. Without their contribution, the SME should hire about 140 additional designers to develop the 150,000 circuits. On Side 2, competitors provide more intense racing experiences because they fill the servers at all times, thus preserving the daily interest in the game. They enrich the creators by using their cars and circuits and they enrich the managers by participating in competitions. Their strong investment in competitions provides an international game dynamic, impossible to reproduce by the 
SME, except by mobilizing hundreds of additional employees. On Side 3, managers put their machine in server mode to organize races and thus provide a steady stream of available races, at the national and international level. They valorize creators by choosing the most interesting circuits and animate races to make them more attractive for competitors. They also manage the racing team. Managers create permanent events and their work is equivalent to the recruitment of dozens of race managers by the SME.

[INSERT Table 2]

Nadeo adopted an open cooperation with user groups by providing a specific value for each of them: (1) for creators, an open tool for content creation, (2) for managers, an open tool for event organization and (3) for competitors, an open access to graphic sources of the game. The content is open to encourage gamers to make contributions, thus optimizing value creation. In turn, the user community optimizes the value proposition by promoting renewal and variety and maintaining the cross-side networks effects, which attract more gamers and thus optimize value capture. Indeed, the more creators there are, the more competitors participate in the game; the more competitors there are, the more creators and managers are involved in their activities; the more managers there are, the more events that attract competitors and creators. Nadeo has also produced an entirely free game version, which has attracted millions of new gamers likely to buy future paid versions of the game. These network effects optimize value creation and value capture because they enhance the value of the offer, increase the gamers' long-term loyalty and keep the innovation dynamic by integrating user contributions in new game versions (Figure 1).

[INSERT Figure 1] 


\subsection{Wakfu's multi-sided BM}

Ankama is a producer of digital creations focused on online video game and transmedia universe. Its flagship transmedia, Wakfu, is an artistic universe in which the story is told on complementary and interconnected media (online video game, animated television series and web collaborative platform). Ankama developed the universe and the media in-house and collaborate with diffusers to broadcast the animated television (TV) series.

The Wakfu's multi-sided BM is composed of three sides which are the three media of the offer (online video game, TV series and web platform) delivered on several markets in which there is a specific group of users. Each side has its own component of value creation, value proposition and value capture, and each side can enrich the other sides complementarily and cumulatively. On side 1, the online video game offers a role-playing game based on the exploration of a heroic fantasy world for a large target market (gamers 12-25 years of age). A toolkit allows gamers to build a part of the world (for example: farms, shops, cities) to create new places of adventure that attract other gamers and enhance the dynamic of the game. The game offers with two types of access: (1) a free restricted access to certain areas of the game and (2) a full paid access with subscription. On side 2, the animated TV series tells the future history of the universe, for the same consumer target market of the game to promote complementarity between the two media. The SME works with a large French television channel that purchases the rights to broadcast the episodes of the series. With the success of the series (because a lot of gamers watch the episodes), Ankama developed other foreign distribution agreements, thus increasing the economic returns. On side 3 , the web platform offers a collaborative space to the user community where converge gamers and television viewers. Various applications (for example: forums, 
blogs, quiz, polls) inform, share and create content relevant to the community. Users can also submit their own content (artistic creation ideas, opinions and votes) by using toolkits provided by Ankama. These contributions enhance the value of the universe because users can improve it.

\section{[INSERT Table 3]}

In Wakfu's multi-sided BM, value optimization is based on complementarity related to the mutual influence of the different media. These media remain independent but are connected and can influence one another depending on the evolution of the narrative and users' actions. Indeed, both the television series and the game are complementary and strongly connected because the story of the heroes in the series may affect the narrative in the game. Similarly, significant actions of gamers and cities created in the game may be included in the TV series. There is also a strong complementarity and interaction between the user community and the various media of Wakfu through the web collaborative platform. Value creation is optimized by the forum system and open collaboration with users, which allows them to be involved in the narrative creation by suggesting improvements for media scenarios, by approving or disapproving of additional content offered by Ankama and by creating their own content. The narrative interconnection between media allows the transfer of user profiles (gamers, viewers and Internet users) on the various Wakfu media, which increases the number of users. This interconnection between media generates cross-side network effects (see Figure 2): TV viewers enrich the Internet user community and potentially increase the number of gamers, which optimizes value capture when gamers pay for the game subscription. Similarly, gamers are encouraged to watch the TV series to obtain clues to advance faster in the game. As the number of gamers increases, the 
number of viewers increases as well. Moreover, high gamer numbers enhance the interest of TV channel by increasing distribution of the animated TV series, which optimizes value capture by the sustainability of revenue. The collaborative dynamic established with the community through forums and other contribution and motivation mechanisms greatly increases the product life of the Wakfu universe because users are personally involved in the evolution of the universe and actively participate in the daily dynamics.

\section{[INSERT Figure 2]}

The two case study show that the optimization of value creation and value capture in a BM is possible by creating complementary sides that each independently add a part of the value proposition but are interdependent with regard to value creation (each side creates value for other sides) and value capture (smaller value capture on one side may increase value capture on another side). Thus, the multi-sided BM is a relevant architecture for value optimization because it provides multiple places for value creation and multiplies sources of value capture, especially in digital industries. Moreover, we show that the structuration of sides can take different forms depending on the type of user needs and diffusion platforms. The first case study (Nadeo/Trackmania) shows a multi-sided BM architecture based on complementary groups of users (creators, managers and competitors) on the market of online video game. Each user group is a side of the $\mathrm{BM}$, and the logic of structuring sides is based on the complementarity of their roles and responsibilities and their open collaboration to the content generation. The second case (Ankama/Wakfu) shows a multi-sided BM architecture based on different technological platforms (media) that deliver a part of the value proposition in different markets (video game, TV and Internet). Each platform on a market is a side of 
the $\mathrm{BM}$, and the logic of structuring sides is based on the narrative complementarity between media and open cooperation among users regarding the content. Thus, a multisided BM can be built from an architecture of user community (with interdependent user categories in one market) or from an architecture of technical platforms (with interdependent platforms of diffusion in multiple markets). However, in both cases, open cooperation about the content and the presence of additional users on complementary sides creates value for the other sides and generates network effects. These results make it possible to discuss various elements relating to (1) the type of value and the type of partner in the optimization of value creation and value capture, (2) the role of digital technologies in a multi-sided BM, (3) the relationship between a multi-sided BM and a user community and (4) the distinction between multi-sided BMs and the other types of BM.

First, the results show that the combination of open cooperation (Pisano and Verganti, 2008) with users regarding content (by using toolkit; Von Hippel, 2001) and the SMEs' internal technology control (control of complementary assets; Teece, 2006) optimizes economic value capture. Open innovation literature tends to emphasize opening of technological value with industrial partners (Chesbrough and others, 2006). This inevitably limits value capture because each partner expects to capture a share of economic value generated by the value created. The distinction between content and technology facilitates the optimization process, especially when the process is carried out with users in a digital environment. Indeed, users' interest in creating value with a firm lies in other motivations (Jeppesen and Frederiksen, 2006) because they prefer to capture a nonmonetary value (for example: artistic content, recognition, experience). In addition, although the complementary sides are based on the interdependence of content, 
the open cooperation favors the network effects due to richer content and more variety. Users' active participation in the creative process allows the firm to more effectively optimizes the value creation than if it were based solely on internal resources (Von Krogh and others, 2003), without reducing its value capture.

Second, the architecture of both multisided BMs studied relies on the use of digital technologies (for example: Internet, mobile and wireless communication protocol, digital networks) that are particularly used to develop multisided Internet platforms because they facilitate networking products, services, and content, which can then be distributed to different complementary user groups in specific market segments (Yoo and others, 2012). In the case of TrackMania and Wakfu, digital technologies are also used to create toolkits for managing open innovation with users, to control the level of openness in the creation of digital content and activities, and to assure a long-term user innovation dynamic (Parmentier and Gandia, 2013). Digital technologies consequently play an important role in designing a multisided BM. In addition, daily renewal of innovation attracts new players, who by becoming paying users help develop the BM's economic efficiency. The adoption of a multisided approach on the Internet thus allows a faster return on a BM based on novelty (product or service innovation) because it is possible to dedicate certain sides to innovation and others to efficiency (product purchases and their extensions), and in particular to address the issue of timeto-market (Zott and Amit, 2008).

Third, adopting a multi-sided approach makes it possible to progress from a novelty-based $\mathrm{BM}$ to an efficiency-based $\mathrm{BM}$ and respond to time-to-market issues (Zott and Amit, 2008). Firms can lock the market and maintain the content creation through the contributions of the user community. The advantage of the Wakfu and 
Trackmania communities is the complementarity and interdependence between the user profiles that generate network effects and ensures sustainable economic returns. Thus, the multi-sided BM is not only a good recipe for value creation and value capture (Baden-Fuller and Morgan, 2010), but also a growth engine in that SMEs can capitalize on sustainable optimization of the existing sides and develop new sides with the user community. Previous research identifies managing the user community as a key element of innovating with users (Parmentier and Mangematin, 2013). The use of toolkits for innovation and social software adapted to each user groups are crucial to obtain their attention and motivation in the value creation (Burger-Helmchen and Cohendet, 2011). The multi-sided BM enables sustainable connections to be developed with users to integrate the value of creativity, knowledge and competencies in the growth engines of firms.

Fourth, the multi-sided BM is clearly different from other types of BM architecture (single BM, BM portfolio and dual BM) from the perspectives of value optimization and its robustness over the long run. Indeed, a firm that bases its business on a single BM risks being unable to evolve quickly enough in the face of profound change in the technological and economic context (Teece, 2010), while the multi-sided $\mathrm{BM}$ allows to explore several sources of value creation and value capture. Even if the BM portfolio makes it possible to test several BMs and quickly adapt the firm activity depending on performance of each model (Sabatier and others, 2010), it requires new skills that may not necessarily be complementary to the SME's initial skills. In the multi-sided BM, the sides are organized depending complementarities between firm skills and user skills. In addition, by providing toolkits for creation of content and activities, the firm can access several user skills and innovations over the long run 
(Parmentier and Gandia, 2013). In the case of dual BM, the user must purchase additional products to access the global offer (Markides and Charitou, 2004) while the multi-sided $\mathrm{BM}$ do not forces the user to consume each side because they are complementary regarding the global offer but interdependent with regard to content. It thus optimizes value creation by opening the creation and value proposition of the most creative sides, and optimizes value capture on the sides with the highest willingness to pay, while maintaining strong network effects that trigger increasing returns to adoption.

\section{CONCLUSION}

Finally, our study contributes to a better understanding of the value organizational logic within a BM, including how a firm can optimize value creation and value capture with a multi-sided approach. Our contribution also lies in the intersection of literature on multi-sided approach and BM literature, which enables us to consider the BM as a plural object, in which each side is a way of creating, proposing and capturing a specific type of value (content, technology or revenue). This contribution is attractive to firms because it encourages managers to rethink the way they design their BM. Thus, we identify two ways to conceive a multi-sided BM architecture: (1) from an architecture based on technical platforms or (2) from a user community architecture. We also provide key mechanisms to organize and optimize value creation and value capture: (1) by opening the content to the contribution of users through toolkits, (2) by making interdependent user groups with complementary roles and responsibilities regarding value creation and value proposition and (3) by interconnecting sides by means of complementary content and activities, to generate positive network effects. More questions remain unanswered: can we design a multi-sided BM for traditional products and services (different cultural products)? What are the determinants of performance 
from one side to another? How do we effectively integrate industrial partners in a multisided BM? The multi-sided BM is an emergent concept that can apply to all industries that involve complementary user and customer categories by using new digital technologies. It allows us to reconsider architecture products, relationships with consumers and firm boundaries. It could also inspire new strategies for firms seeking to spread their innovations effectively, despite the many existing barriers in mature markets. 
Table 1: Internal and external data collected between 2007 and 2009

\begin{tabular}{|c|c|c|}
\hline & Nadeo/Trackmania & Ankama/Wakfu \\
\hline $\begin{array}{c}\text { Internal } \\
\text { data }\end{array}$ & $\begin{array}{l}\text { - } 3 \text { interviews of the SME's director to } \\
\text { understand the strategy, the } \\
\text { development of Trackmania and the } \\
\text { different choices made to elaborate } \\
\text { the multi-sided BM } \\
\text { - } 2 \text { interviews of community managers } \\
\text { to understand the Trackmania } \\
\text { community } \\
\text { - } 18 \text { players heavily involved in the } \\
\text { community, to understand their } \\
\text { motivations and their practices inside } \\
\text { and around the game }\end{array}$ & $\begin{array}{l}\text { - } 18 \text { semi-directive interviews: } \\
\text { artistic director (3), team managers } \\
\text { (9) and community mangers (6) to } \\
\text { understand the SME’s strategic } \\
\text { behavior, the development of } \\
\text { Wakfu and the elaboration of the } \\
\text { multi-sided BM. } \\
\text { - } 16 \text { internal documents: meeting } \\
\text { reports (7), project folder (1) and } \\
\text { user community reports (8) to } \\
\text { complete our knowledge about } \\
\text { Wakfu community and multi-sided } \\
\text { BM }\end{array}$ \\
\hline $\begin{array}{c}\text { External } \\
\text { data }\end{array}$ & \multicolumn{2}{|c|}{$\begin{array}{l}\text { We conducted a longitudinal documentary research on the communities' websites } \\
\text { (especially forums, to identify user contributions) and in the specialized press (major } \\
\text { video game websites such as jeuvideo.com and gamekult.com and large video game } \\
\text { institutions such as } \mathrm{AFJV}^{3}, \mathrm{SNJV}^{4} \text { ) to complete our knowledge about Trackmania } \\
\text { and Wakfu. }\end{array}$} \\
\hline
\end{tabular}

\footnotetext{
${ }^{3}$ French Association for the Video Game (www.afjv.com)

${ }^{4}$ National Syndicate for the Video Game (www.snjv.org)
} 
Table 2. Trackmania's multi-sided BM

\begin{tabular}{|c|l|l|l|}
\cline { 2 - 5 } \multicolumn{1}{c|}{} & \multicolumn{1}{c|}{$\begin{array}{c}\text { CREATOR - } \\
\text { Side 1 }\end{array}$} & \multicolumn{1}{c|}{$\begin{array}{c}\text { COMPETITOR } \\
\text { Side 2 }\end{array}$} & \multicolumn{1}{c|}{$\begin{array}{c}\text { MANAGER } \\
\text { Side 3 }\end{array}$} \\
\hline creation & $\begin{array}{l}\text { Users: Creation of } \\
\text { circuits, cars and videos. } \\
\text { Nadeo: Tool kits for } \\
\text { content creation }\end{array}$ & $\begin{array}{l}\text { Users: Participation } \\
\text { in races. } \\
\text { Nadeo: Online race } \\
\text { game }\end{array}$ & $\begin{array}{l}\text { Users: Organization of } \\
\text { races and competitions. } \\
\text { Management team race. } \\
\text { Nadeo: Toolkits for event } \\
\text { creation }\end{array}$ \\
\hline $\begin{array}{c}\text { Value } \\
\text { proposition }\end{array}$ & $\begin{array}{l}\text { Users bring more than } \\
\text { 150,000 cars and circuits. } \\
\text { They contribute to the } \\
\text { diversity of the game and } \\
\text { the renewal of the offer. } \\
\text { Nadeo provides a game } \\
\text { with toolkits and } \\
\text { integrates user content } \\
\text { directly in game. }\end{array}$ & $\begin{array}{l}\text { Users fill servers at } \\
\text { all times. They } \\
\text { make the most } \\
\text { intense and } \\
\text { interesting races. } \\
\text { Nadeo provides an } \\
\text { online game with a } \\
\text { list of races. }\end{array}$ & $\begin{array}{l}\text { Users participate in } \\
\text { hundreds of race online at } \\
\text { all times. They help } \\
\text { develop a variety of races } \\
\text { and competition. } \\
\text { Nadeo provides a game } \\
\text { with tool kits and integrates } \\
\text { event directly in the game }\end{array}$ \\
\hline \multirow{2}{*}{$\begin{array}{l}\text { Value } \\
\text { capture }\end{array}$} & $\begin{array}{l}\text { Activities of creation and organization of gamers are not paid. Contents and } \\
\text { events are directly integrated in the offer. They are the equivalent of hundreds } \\
\text { of jobs that the producer does not have to pay. The offer includes Trackmania } \\
\text { paid versions and free versions to reward gamers. } \\
\text { Nadeo captures monetary value and the creativity of users. }\end{array}$ \\
& $\begin{array}{l}\text { Users capture value with a game with more content and events, and } \\
\text { knowledge and reputation. }\end{array}$ \\
\hline $\begin{array}{l}\text { Interaction } \\
\text { other sides }\end{array}$ & $\begin{array}{l}\text { High: Side 2 } \\
\text { Low: Side 3 }\end{array}$ \\
\hline
\end{tabular}


Table 3. Wakfu's multi-sided BM

\begin{tabular}{|c|c|c|c|}
\hline & $\begin{array}{l}\text { Online video game } \\
\text { gamers (Side 1) }\end{array}$ & $\begin{array}{c}\text { Animation } \\
\text { television } \\
\text { viewers (Side 2) }\end{array}$ & $\begin{array}{c}\text { Web } 2.0 \\
\text { Internet users (Side 3) }\end{array}$ \\
\hline $\begin{array}{l}\text { Value } \\
\text { creation }\end{array}$ & $\begin{array}{l}\text { - Ankama: game and } \\
\text { content } \\
\text { - Users: content }\end{array}$ & $\begin{array}{l}\text { - Ankama: content } \\
\text { - Users: nothing }\end{array}$ & $\begin{array}{l}\text { - Ankama: technological } \\
\text { platform and content } \\
\text { - Users: content }\end{array}$ \\
\hline $\begin{array}{c}\text { Value } \\
\text { proposition }\end{array}$ & $\begin{array}{l}\text { - Ankama: MMORPG } \\
\text { for 12- to 25-year-olds } \\
\text { based on heroic } \\
\text { fantasy universe } \\
\text { - Users: content }\end{array}$ & $\begin{array}{l}\text { - Ankama and } \\
\text { television broadcaster: } \\
\text { animated series } \\
\text { - Users: nothing }\end{array}$ & $\begin{array}{l}\text { - Ankama: Wakfu } \\
\text { community website with } \\
\text { application to inform, } \\
\text { share and create content } \\
\text { - Users: content }\end{array}$ \\
\hline $\begin{array}{l}\text { Value } \\
\text { capture }\end{array}$ & $\begin{array}{l}\text { - Free limited access } \\
\text { - Paid full access } \\
\text { through subscription } \\
\text { - Capture of content } \\
\text { created by users }\end{array}$ & $\begin{array}{l}\text { - Purchase by } \\
\text { television broadcaster } \\
\text { - free for spectators }\end{array}$ & $\begin{array}{l}\text { - free for all } \\
\text { - Capture of content } \\
\text { created by users }\end{array}$ \\
\hline $\begin{array}{l}\text { Interaction } \\
\text { other sides }\end{array}$ & $\begin{array}{l}\text { High: side } 2 \\
\text { Low: side } 3\end{array}$ & $\begin{array}{l}\text { High: side } 1 \\
\text { Low: side } 3\end{array}$ & High: side 1, 2, 3 \\
\hline
\end{tabular}


Figure 1: Value transaction in Trackmania's multi-sided BM

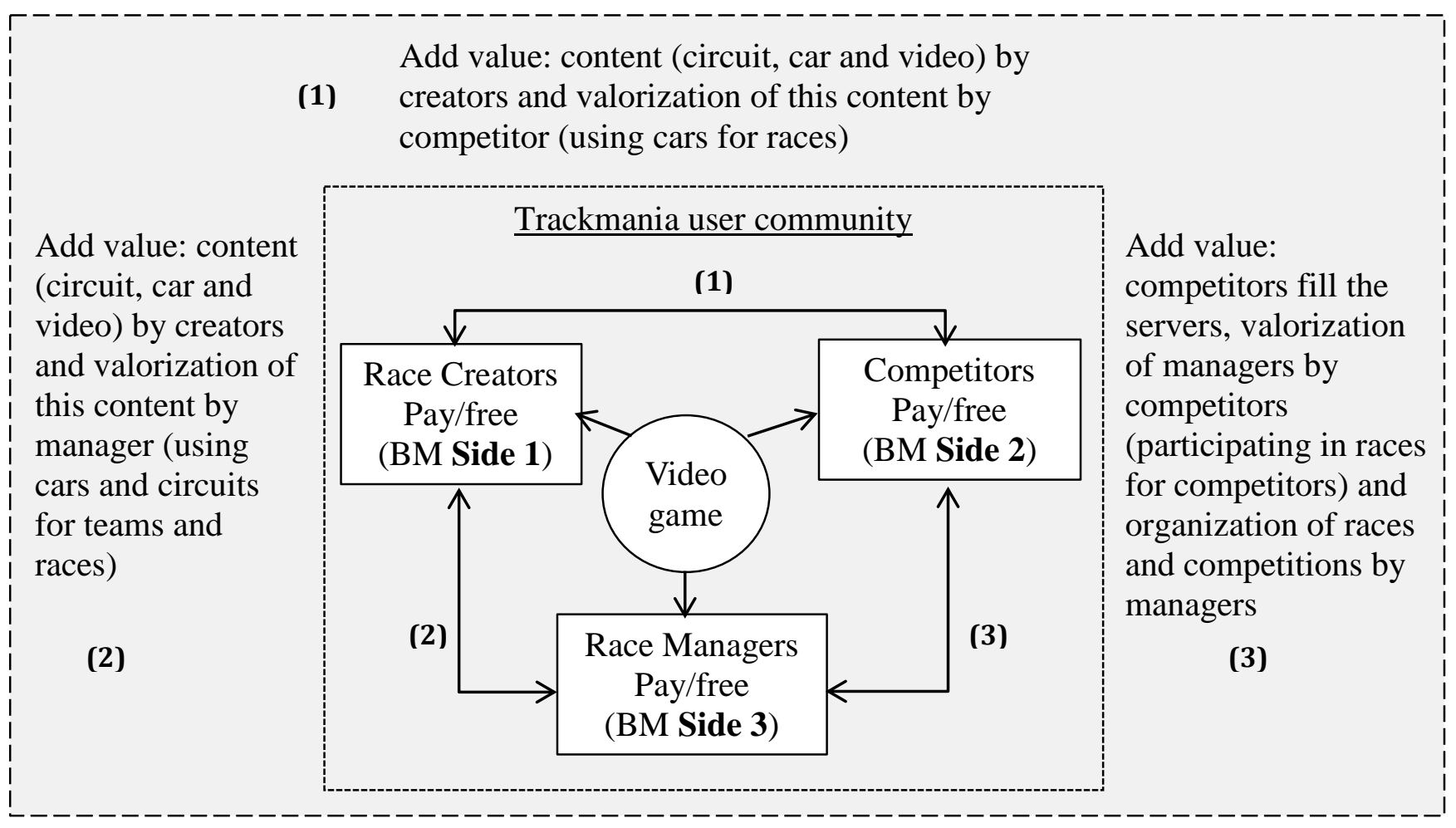


Figure 2. Value transaction in Wakfu's multi-sided BM

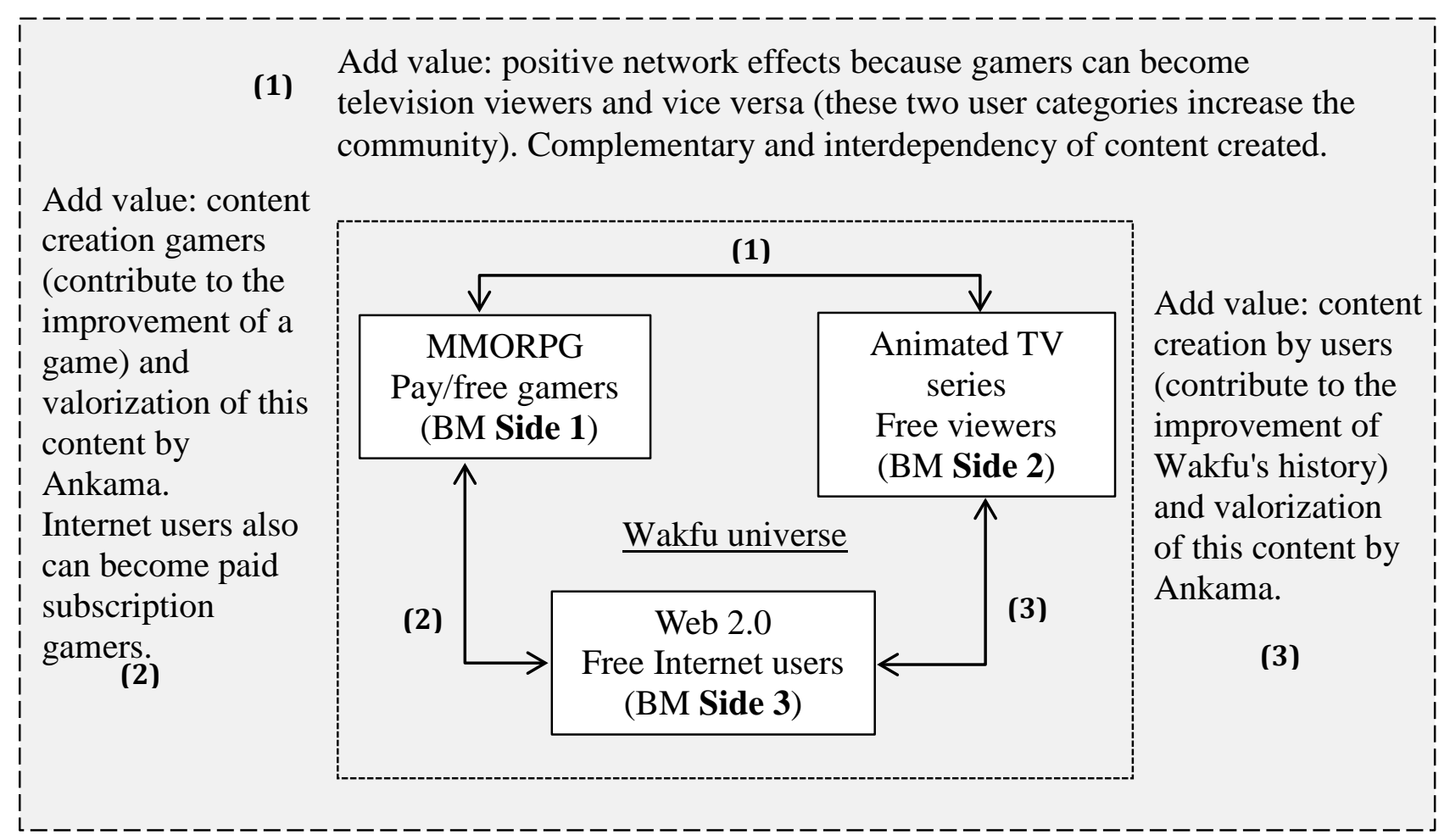




\section{REFERENCES}

Albuquerque P, Pavlidis P, Chatow U, Chen KY, Jamal Z. 2012. Evaluating Promotional Activities in an Online Two-Sided Market of User-Generated Content. Marketing Science; 31(3): 406-432. DOI: 10.1287/mksc.1110.0685.

Baden-Fuller C, Morgan MS. 2010. Business Models as Models. Long Range Planning; 43(2/3): 156-171. DOI: 10.1016/j.lrp.2010.02.005.

Burger-Helmchen T, Cohendet P. 2011. User Communities and Social Software in the Video Game Industry. Long Range Planning; 44(5/6): 317-343. DOI: 10.1016/j.lrp.2011.09.003.

Casciaro T, Piskorski MJ. 2005. Power Imbalance, Mutual Dependence, and Constraint Absorption: A Closer Look at Resource Dependence Theory. Administrative Science Quarterly; 50: 167-199. DOI: 10.2189/asqu.2005.50.2.167.

Chesbrough HW. 2007. Why Companies Should Have Open Business Models. MIT Sloan Management Review; 48(2): 22-28.

Chesbrough HW, Appleyard MM. 2007. Open Innovation and Strategy. California Management Review; 50: 57-76.

Chesbrough H, Rosenbloom RS. 2002. The Role of the Business Model in Capturing Value from Innovation: Evidence from Xerox Corporation's Technology Spin-Off Compagnies. Industrial and Corparate Change; 11: 529-555. DOI: 10.1093/icc/11.3.529.

Chesbrough H, Vanhaverbeke W, West J. 2006. Open Innovation: Researching a New Paradigm. Oxford University Press: New York.

Dahlander L, Magnusson M. 2008. How Do Firms Make Use of Open Source Communities. Long Range Planning; 41: 629-649. DOI: 10.1016/j.lrp.2008.09.003.

Dubosson-Torbay M, Osterwalder A, Pigneur Y. 2002. E-Business Model Design, Classification, and Measurements. Thunderbird International Business Review; 44(1): 5-23.

Eisenmann T, Parker G, Alstyne MWV. 2006. Strategies for Two-Sided Markets. Harvard Business Review; 84(10): 92-101.

Evans DS, Schmalensee R. 2007. The Industrial Organization of Markets with TwoSided Platforms. Competition Policy International; 3: 151-179. DOI: 10.3386/w11603.

Fichter K. 2009. Innovation Communities: The Role of Networks of Promoters in Open Innovation. R\&D Management; 39(4): 357-371. DOI: 10.1111/j.14679310.2009.00562.

Gulati R, Stych M. 2007. Dependence Asymmetry and Joint Dependence in Interorganizational Relationships: Effects of Embeddedness on a Manufacturer's Performance in Procurement Relationships. Administrative Science Quarterly; 52: 32-69. DOI: 10.2189/asqu.52.1.32.

Jeppesen LB, Frederiksen L. 2006. Why Do Users Contribute to Firm-Hosted User Communities? The Case of Computer-Controlled Music Instruments. Organization Science; 17(1): 45-63. DOI: 10.1287/orsc.1050.0156.

Johns J. 2006. Video Games Production Networks: Value Capture, Power Relations and Embeddedness. Journal of Economic Geography; 6(2): 151-180. DOI: 10.1093/jeg/lbi001.

Katz ML, Shapiro C. 1992. Product Introduction with Network Externalities. Journal of Industrial Economics; 40(1): 55-83. DOI: 10.2307/2950627. 
Lepak DP, Smith KG, Taylor MS. 2007. Value Creation and Value Capture: A MultiLevel Perspective. Academy of Management Review; 32(1): 180-194. DOI: 10.5465/AMR.2007.23464011.

Markides C, Charitou CD. 2004. Competing with Dual Business Models: A Contingency Approach. Academy of Management Executive; 18: 22-36. DOI: 10.5465/AME.2004.14776164.

Miles MB, Huberman AM. 1994. Qualitative Data Analysis: An Expanded Sourcebook. Sage Publications: Thousand Oaks, CA.

Parmentier G, Gandia R. 2013. Managing Sustainable Innovation with a User Community Toolkit: The Case of the Video Game Trackmania. Creativity and Innovation Management; 22(2): 195-208. DOI: 10.1111/caim.12021.

Parmentier G, Mangematin V. 2013. Orchestrating Innovation with User Communities in the Creative Industries. Technological Forecasting \& Social Change; 83: 40-53. DOI: 10.1016/j.techfore.2013.03.007.

Pisano GP, Teece DJ. 2007. How to Capture Value from Innovation: Shaping Intellectual Property and Industry Architecture. California Management Review; 50: 278-296.

Pisano GP, Verganti R. 2008. Which Kind of Collaboration Is Right for You?. Harvard Business Review; 86: 78-86.

Porter ME. 2001. Strategy and the Internet. Harvard Business Review; 79: 1-20.

Rochet JC, Tirole J. 2003. Platform Competition in Two-Sided Markets. Journal of the European Economic Association; 1(4): 990-1029.

Rochet JC, Tirole J. 2006. Two-Sided Markets: A Progress Report. RAND Journal of Economics; 37(3): 645-667. DOI: 10.1111/j.1756-2171.2006.tb00036.x.

Roson R. 2005. Auctions in a Two-Sided Network: The Market for Meal Voucher Services. Networks \& Spatial Economics; 5(4): 339-350.

Sabatier V, Mangematin V, Rousselle T. 2010. From Recipe to Dinner: Business Model Portfolios in the European Biopharmaceutical Industry. Long Range Planning; 43(2/3): 431-447. DOI: 10.1016/j.lrp.2010.02.001.

Shuen A. 2008. Web 2.0: A Strategy Guide. O’Reilly Media Inc: Sebastopol, CA.

Stuart T. 2000. Inter-Organizational Alliances and the Performance of Firms: A Study of Growth and Innovation Rates in a High-Technology Industry. Strategic Management Journal; 21(8): 791-811. DOI: 10.1002/1097-0266.

Teece DJ. 2006. Reflections on 'Profiting from Innovation'. Research Policy; 35: 11311146. DOI: 10.1016/j.respol.2006.09.009.

Teece DJ. 2010. Business Models, Business Strategy and Innovation. Long Range Planning; 43(2/3): 172-194. DOI: 10.1016/j.lrp.2010.07.003.

Von Hippel E. 2001. Perspective: User Toolkits for Innovation. Journal of Product Innovation Management; 18: 247-257. DOI: 10.1016/S0737-6782.

Von Krogh G, Spaeth S, Lakhani KR. 2003. Community, Joining, andSpecialization in Open Source Software Innovation: A Case Study. Research Policy; 32: 1217-1241. DOI: 10.1016/S0048-7333.

Wirtz BW, Schilke O, Ullrich S. 2010. Strategic Development of Business Models: Implications of the Web 2.0 for Creating Value on the Internet. Long Range Planing; 43(2/3): 272-290. DOI: 10.1016/j.lrp.2010.01.005.

Wolff J, Pett T. 2006. Small Firm Performance: Modeling the Role of Product and Process Improvements. Journal of Small Business Management; 44: 268-284. DOI: $10.1111 / \mathrm{j} .1540-627 \mathrm{X}$. 
Yin KR. 2003. Case Study Research, Design and Method. Sage: Thousand Oaks, CA.

Yoo Y, Boland RJ, Lyytinen K, Majchrzak A. 2012. Organizing for Innovation in the Digitized World. Organization Science; 23(5): 1398-1408. DOI: 10.1287/orsc.1120.0771.

Yunus M, Moingeon B, Lehmann-Ortega L. 2010. Building Social Business Models: Lessons from the Grameen Experience. Long Range Planning; 43(2/3): 308-325. DOI: 10.1016/j.lrp.2009.12.005.

Zott C, Amit R. 2008. The Fit Between Product Market Strategy and BM: Implications for Firm Performance. Strategic Management Journal; 29: 1-28. DOI: 10.1002/smj.642.

Zott C, Amit R. 2010. Business Model Design: An Activity System Perspective. Long Range Planning; 43(2/3): 216-226. DOI: 10.1016/j.lrp.2009.07.004. 